Journal Of Al Azhar University Engineering Sector

Vol. 12, No. 42, January, 2017, 1-13

\title{
A SURVEY OF PROJECT MANAGEMENT MATURITY FOR CONSTRUCTION CONTRACTORS IN EGYPT: THE CURRENT STATUS
}

\author{
Mohamed H. Moutawei ${ }^{1}$, Ahmed S. Mohamed ${ }^{2}$, Moheeb E. Ibrahim ${ }^{2}$ \\ and Mohamed A. Bakry ${ }^{3}$ \\ ${ }^{1}$ Orascom Construction Industries, Cairo, Egypt. \\ ${ }^{2}$ Construction Engineering \& Management, Structural Engineering Department, Faculty of \\ Engineering, Cairo University. \\ ${ }^{3}$ Director of Strategic Management Department, Social Fund for Development, Egypt.
}

\begin{abstract}
Project Management is considered now one of the most dynamic and growing professions worldwide. Effective project management not only reduces unnecessary costs of doing business, but also has become as a crucial factor to gain a competitive advantage and determines the success and survive of organizations. In the last decade, there is a global international interest and attention for organizations to evaluate and improve the effectiveness of its project management practices. Given such background, this clarifies the dramatic increase in the attention, research and practices of the project management maturity and the maturity models. Maturity Models has taken on greater significance not only in assessing organization's current project management capabilities and efficiency, but also as a path for achieving excellence in project management and further performance improvement. The capability maturity model, the first maturity model developed, has achieved a wide success and Organizations implementing this approach experience and report significant benefits and return on investment. Various models have since been developed and proposed, and they are most commonly implemented in developed countries such as USA, UK, Canada, Europe, etc. The excessive variety of maturity models has made the choice between them difficult and need careful attention and consideration in both the model choice and implementation in the business. In Egypt, there is a lack of documentation available on the current status, awareness and utilization of maturity models in the contracting organizations working in the construction sector and this study aims to fill this gap. To achieve this, it was necessary to consult project management experts and professionals to get an understanding of how these organizations view maturity models and project management standards and to establish the most common business practices and so propose the basis of a maturity model for Egyptian construction contractors that best fits the current status.

Based on the analysis of the survey conducted, it was concluded that project management tools and methodologies have not yet been utilized effectively in the Egyptian construction contracting organizations and that there is much room for improvement regarding project management practices in these organizations in order for Egypt to develop the contracting construction sector as a pillar for the Egyptian economy.
\end{abstract}

Keywords: Construction Industry, Egypt, Project Management. 


\section{INTRODUCTION}

The construction industry is one of the largest industries in the world and plays significant role in the economy of both developed and developing countries. In leading industrial countries, construction investment, expressed as percentage of gross national product ranges from approximately $4 \%$ in USA and $6 \%$ in Canada to $7 \%$ in UK and $10 \%$ in Japan. For developing countries, major construction activities account for approximately $80 \%$ of the overall capital assets, $10 \%$ of their GDP, and greater than $50 \%$ of the wealth invested in fixed assets.

Additionally, the construction business offers great employment opportunity, possibly next after agriculture [1]. Moreover, the construction industry provides physical facilities satisfying a wide

variety of social, economic and technical needs. In addition, it is the backbone of a variety of secondary feeding industries through which it acts as a major source of employment and upgrading of specialized skills.

The pivotal role of management practices in construction projects has become a crucial factor for the success of the construction organizations. The role of project management in construction has become well researched. Among the mainstream understandings is that poor managerial capabilities are one of the crucial problems in the construction industry. Globalization, business environmental has posed several kinds of challenges and the level of skills demanded in the international market has grown rapidly in recent years. The unstable international economic status has meant that organizations are constantly requested to revise their actions and practices to ensure survival. It is even more essential that construction projects adhere to the estimated budget and completion deadline. Performance must be excellence because competition is fierce.

As a result, several construction organizations are seeking their profitability and survival in enhancing the efficacy of their management practices to achieve the organizational objectives. Project management maturity models have arisen in this regard as a response to the need for organizations to evaluate their project management practices, compare themselves with other organizations in their field in order to achieve excellence and ensure survival. Maturity Models are models designed to provide a way for organizations to understand their project management practices and to evaluate their maturity against an extensive set of project management best practices. In other words, PM maturity models are models developed to help organizations determine their level of maturity (efficiency) in their project management practices and compare themselves with other organizations in their field in order to achieve excellence and ensure survival.

Through the selection of the maturity model and the correct practical implementation in the business, the strengths and weaknesses of the organizational project management practices can be well identified with a structured roadmap for improvement of these practices. Several previous studies and authors such as Kerzner [21], Sukhoo [11], Kwan and Ibbs [27], Schlitz [13], Soninke's and Launching [12], Archibald and Paradox [3] and several others have shown a direct relation between the correct implementation of project management maturity models and the success of projects. The measurements and results of recent extensive studies results conducted in Brazil, Untied States, Italy and other countries have been frequently published in the PM World Journal and can be accessed in the website www.maturityresearch.com.

Given the above, several project management maturity models have been developed and utilized in several developed countries such as USA, Canada, UK, Europe, etc. In Egypt, there is a lack of documentation available on the current status and utilization of maturity models in the construction contracting organizations. This paper constitutes a part of a larger research project aims to fill this gap. To achieve this, an extensive literature review has been conducted on the predominant existing maturity models, a market survey to assess the current status of 
maturity awareness and implementation in the construction contracting organizations has been developed and distributed in coordination with the Egyptian Federation for Construction \& Building Contractors (EFCBC). This research is justified by the need to clarify the vision of maturity models and its implementation in the Egyptian contracting organizations, as well as the need to develop a model that meets their requirements more closely.

Given such background, this paper aims at gaining understanding of how contracting organizations view maturity models and project management standards and exploring its current status and implementation. The need for application of the best practices in these organizations has increased and became a focal point in Egypt [5]. Egypt's emerging market economy demanded new forms of management, which in turn gave a stimulus for new avenues in development of project management profession in the construction industry. However, with regard to project management maturity vison and implementation in these organizations in Egypt, the review by the author revealed lack of research or trails to explore the issue.

\section{STATEMENT OF THE PROPLEM}

In spite of the construction industry's substantial involvement in the overall economy of developing countries and the critical role it plays in the development of these countries, the performance of the industry still remains generally low. As Idoko (2008), noted, “...many projects in developing nations encounter significant cost and time overruns, fail to realize their aimed benefit or may be even completely terminated and abandoned before or even after their completion..." [4]. Moreover, the development of the construction industry in developing nations usually lags significantly behind from other industries in those nations and also their counter parts in developed nations. Generally, as Ofori (2006) concluded "The construction industry in developing nations failed to fulfill expectations of customers, governments and even society as a whole" [1].

Similar to the case along with other developing nations, the Egyptian construction industry shares most of the problems and challenges the industry is facing in other developing nations, maybe with greater severity. Given that, Egypt, as a developing country, needs several major national projects like water, wastewater, and transportation projects; also, considering the critical role the construction industry plays in Egypt and other developing countries, and the poor level of performance of the industry in these countries, improving the overall performance of the construction industry ought to be a high priority action.

Since contractors are among the crucial players in the construction industry and the makers of the end product, any level of development and enhancement initiatives in the industry should consider improving the capacity and capability of the contractors. Given that there are a lot of unprecedented Mega and Giga projects in the region and that the Egyptian contractors have a great opportunity to export their contracting services in the region and increasing the national income and the employment opportunities; moreover, considering, the competition in the region is becoming very tough and challenging; as new and international contractors (including Chinese and Indian companies) are emerging into the market. Furthermore, Improving the capacity and capability of Egyptian contractors has been announced by the Egyptian government to be one of its priorities [5]. Given all these factors, improving the capacity and capabilities of Egyptian construction contractors ought to be one of the highest priority actions.

Earlier research works by several authors, such as, Adams [6] and Long [7] have showed poor managerial capability of contractors to be certainly one of the crucial problems of the construction industry in developing nations. Thus, improving the managerial capability of contractors need to be one of the priority considerations for improvement. Researches by (Dlungwana \& Rwelamila) have also strongly emphasized the importance of enhancement the management skills of contractors [8]. 
Systematic and continuous development exertion needs understanding of exactly where the present status of the management practices is, where desired to go, and the gap between the two. Additionally, systematic and sustained enhancement endeavor demands identifying critical and priority areas, continually assessing results of improvement efforts and taking appropriate actions. So far, there is a lack of research and documentation in Egypt in this regard and this study aims to fill this gap. This paper constitutes a part of a larger research project focusing on assisting the Egyptian construction contractors in evaluating and improving their project management practices and capabilities.

Three main studies have been conducted to this end: firstly, an extensive literature review of how the problem was solved on both the practitioner's and academic levels worldwide; and, secondly an extensive literature of the maturity concept, evolvement, models along with a comparison of existing maturity models has been conducted. Thirdly, a field survey of Egyptian construction contractors was conducted to gain an understanding of how contracting organizations view maturity models and project management standards.

\section{A REVIEW OF PROJECT MANAGEMENT MATURITY}

To measure the project management maturity, several models have been developed and utilized during the last 2 decades. Although these models vary from simple to very complex, but they share the common goal whose objectives are to identify where the project management enhancements are needed, give clear indication of the strengths and weaknesses of the project management practices, lead to significant competitive advantages, and benchmark an organization against its competitors [18] [2].

The basis of the maturity models may extend to Crosby's model in 1979. Crosby structured his famous model known as QMMG, which stands to "the quality Management Maturity Grid". The model was based on 5 levels of maturity, which are linked to the adoption of quality principals within the organization. In 1986, Deming proposed several practices for the continuous improvement of quality management process within the organizations. These practices included the Deming Cycle (PDCA); which consist of four repeated stages: 1. Plan, 2. Do, 3. Check, and 4. Act. Based on the Crosby model and the Deming circle, a model to evaluate and encourage the management of software process was developed by United States defense department and the Software Engineering Institute (SEI) at Carnegie Mellon University. The model was known as the Capability Maturity Model (CMM).

The development of CMM started in 1987 and the initial version was released in 1991. The main objective of the CMM is the enhancement of the processes conducted in the software engineering projects. The model consists of 5 levels of maturity for evaluation 18 process areas, 52 objectives, and over 300 key practices [14]. The success of the CMM in the software industry inspired experts in several fields including the project management field to develop several other maturity models; consequently, several and valuable maturity models in the project management field have been developed during the last two decades.

The (CMMI) stands for the Capability maturity model integration, which was released in 2000 as a successor to the CMM with more general application. CMMI integrates areas such as services, product development and software engineering. CMMI version 1.3, which was released in 2010, is currently covers three areas of interest and offers the following three maturity models: CMMI-SVC (capability maturity models for services), CMMI-DEV (Capability maturity model for development) and CMMI-ACQ (Capability maturity model for Acquisition) [23] [24].

Harold Kerzner in 2001, proposed a maturity model to evaluate the project management maturity for organizations known as K-PMMM. The model has five levels and emphasizes benchmarking and makes benchmarking the forth level in the model. the author has identified the characteristic at every maturity level, the 'roadblocks', 'risks', and essential actions required to finish this level. The model is applied through a questionnaire - interview that 
consists of 183 questions and divide the results into various scores and considers the maturity model from the strategic planning point of view [25] [21].

Also, in 2001, the project Management Solution Software in the United States developed the PM Solutions-PMMM. As explained by Crawford (2015), this model is created by mirroring ten knowledge areas of the PMBOK with that five level maturity stage of the CMM's. The model verifies an organization's PM realization across the ten Project Management knowledge areas, which are, on the other hand, divided into processes. In their handbook, the model's developers have presented a comprehensive explanation of the attributes of the knowledge area at every maturity level [22]. The model is easy to understood and readily operational, and therefore was accepted easily. The project portfolio management maturity model (PMS-PPMMM) was released soon afterwards and added the portfolio dimension to the model.

The Advanced Engineering Association of Japan (ENAA) released in 2001 the P2M maturity model, which stands for the project and program management for enterprise innovation. The model is based on Kaikaku project management (KPM). In this model, the maturity is classified into five levels: Haphazard, Systematic, scientific, integrated and optimization. The model aimed to encourage the idea of Intellectual property for both managers and workers in preference to technology skills in project management [26].

In 2002, the project management process maturity model (Pm2) was introduced by the University of Berkeley (William C. Ibbs and Kwak) as a more comprehensive maturity model to evaluate and compare the maturity of the organizations. The model breakdowns Project Management processes and practices into Project Management knowledge areas and phases of processes adopting PMBOK's division. The model evaluates the project management maturity of an organization through the evaluation of those knowledge areas and phases [27].

In 1998, the PMI launched the development of the organizational project management maturity model program (OPM3) to pursue the recognition of this model as a global standard and it aims to help organizations to transfer strategy into successful performance. The OPM3 model is arranged in three elements connected together (knowledge; assessment; and improvement) and it covers three domains (portfolio management, program management and project management). The model has three interrelated components in every domain (best practices; capabilities; and outcomes) and has four stages of enhancement (SMCI), which are: standardize, measure, control and continuous improvement [19].

In 2004, the office of Government Commerce (OGC) launched a maturity model for the project dimension (PjM3). This later evolved into the Prince 2 maturity model, which specifically is maturity model for the organizations utilizing the Prince 2 methodology. In the same year Vienna University of economics and business administration introduced the Cobweb model; which is a six level maturity model for the self-assessment and benchmarking of organizations. In 2006, the OGC launched a complete version of P3M3 which includes portfolio, program and project management dimensions for any project based organization [2].

As stated by Axelos Limited (2013), the P3M3 provides a framework can evaluate the current performance of organizations and plan for improvement during managing and delivering change. The model has three sub models that may be used separately to focus on particular areas of business and more generally to assist organizations to evaluate the projects, programs and portfolios [36]. Therefore, P3M3 considers not only the activities carried out at the individual program and project level, but also the activities within the organization that provide focus and help sustain effort to build an infrastructure for effective management practices [16] [17]. 
The IPMA Delta model integrates the state-of-the art know how covering a 360-degree perspective of organizational competence in PM. The standard comprises three domains. It uses the IPMA competence baseline to evaluate the competence of selected individuals (Module I) and the IPMA project excellence model to evaluate the project management competence and results in selected projects and programs (Module P). Finally, Module O is utilized to evaluate the organizational competence in managing projects based on the IPMA organizational competence base line standard (IPMA OCB) [28].

\section{RESEARCH OBJECTIVES}

The aim of this paper is to present the results of the field survey conducted in Egypt for Construction contractors regarding their vision of maturity and its implementation. The survey was conducted by the Author in 2016 in coordination with the Egyptian Federation for Construction \& Building Contractors (EFCBC).

With the purpose of clarifying the vision of maturity and its implementation in the Egyptian construction contracting organizations, gaining understanding of how these organizations view maturity models and project management standards, and filling a local maturity research gap, this work provides a study on assessing the awareness and implementation of the current status of project management maturity in the country.

\section{RESEARCH METHODOLGY}

In order to develop the framework that responds to the current status of contracting organizations working in the Egyptian construction industry, we must first understand their level of knowledge about the project management international standards and its methodologies along with the project management activities that have been carried out by these organizations. To conduct this study, we chose to use expert judgement gathered through a survey of Industry professionals. The participants were mostly professionals and experts in project management working in the Egyptian construction contracting organizations. An on-line survey was developed and sent to the construction contracting organizations. In addition to that, the author set a partnership with several project management companies, providing management consulting and training services in Egypt. These companies sent the Expert Judgement survey via e-mail to project managers, experts and professionals in the construction industry who had been trained by these companies. Moreover, the survey was conducted in coordination with the Egyptian Federation for Construction \& Building Contractors (EFCBC) and published on their web site. Several workshops have been held with contracting organizations to explain the subject, have a live discussion and feedback about it.

The survey was divided into three parts. The first part consists of 6 questions of personal nature to help position the respondents' profile. The second part consists of 5 questions aiming at exploring the profile of the contracting organization. The third part consists of 11 multiple choice questions regarding the organizational utilization of project management standards and maturity models. In addition, information was also gathered on the level of maturity as well as the level of success within the contracting organizations with respect to project completion time, cost and results. The questions in the survey are related to the major famous international project management standards and maturity models. The respondent was always given the choice to state that they utilize other standards or systems not indicated, or don't know the answer or that they are not sure to answer satisfactorily; thus, avoiding forced or unrealistic answers.

A total of one hundred sixteen people responded in spite of several e-mails sent in order to increase the reply rate. One of the main reasons known for the low response rate was that there's no enough time to fill in the survey. To complete part three of the survey participant spends, on the average ten - fifteen minutes and around twenty minutes are required to respond to all the three parts of the survey. 


\section{RESULTS AND DISCUSSION}

The data from the Expert Judgement survey targeting contracting organizations working in the Egyptian construction sector were used to determine, among others, main two objectives:

- The Awareness and Implementation of both Maturity Models and project management methodologies/ standards in the construction contracting organizations.

- Assessment of Construction Project Management Maturity Level for the Egyptian Construction Contracting Organizations.

The analysis of the data collected in the questionnaire survey for the above two main objectives are discussed in details in the next two sub sections.

6.1. Assessment of Awareness and Implementation of Both Maturity Models and Project Management Methodologies/ Standards: The Current Status. Awareness and Implementation of Maturity Models

A comprehensive analysis to the responses to the questionnaire survey was conducted. From the analysis, it can be concluded that Egyptian Contracting organizations are generally unaware of the value of project management maturity models for appraisal and improvement of project management practices. This lack of awareness implies that these maturity models are not implemented, and accordingly deficiencies and lessons learned in their utilization cannot be identified.

Awareness and Implementation of project management methodologies/

International Standards

It was found generally that Egyptian contracting organizations were not using formally any international project management methodology/ standards. Information on awareness and familiarity of some popular project management methodologies/ standards was sought from the participants. The result (Figure 1) showed that, except the PMBOK and IPMA, the majority scored less than 5\% regarding their familiarity among participants. The most popular methodology/standard being $P M B O K^{\circledR}$, while P2M and APM were the least know among participants in the Egyptian construction contracting organizations.

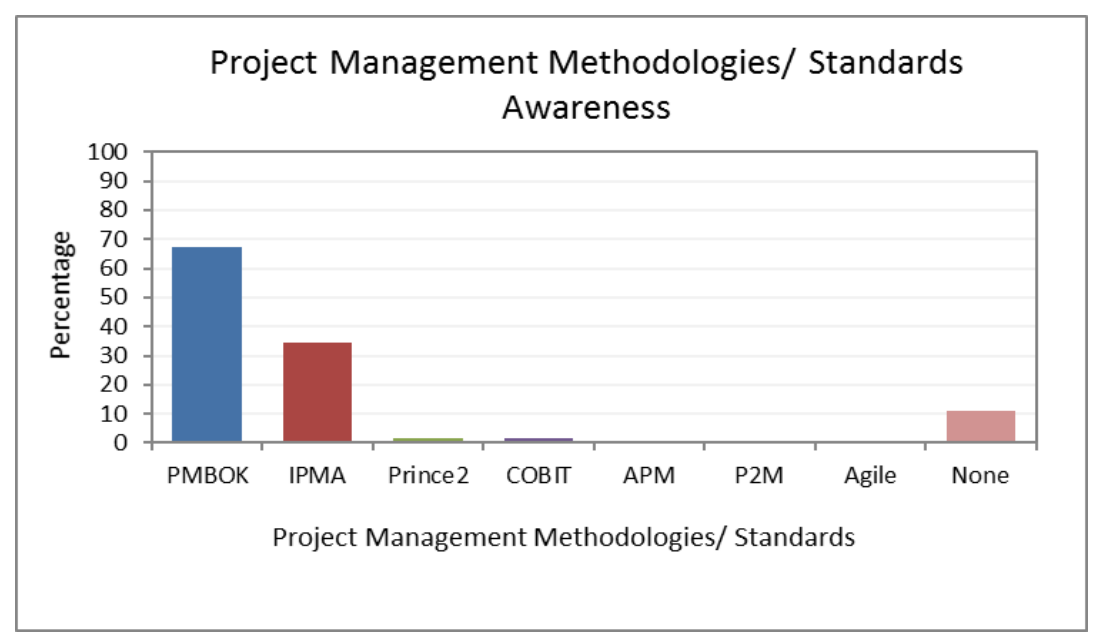

\section{Figure 1: Awareness of Project Management Methodologies/ Standards \\ 6.2. Assessment of Project Management Maturity for Contracting Organizations Working in the Egyptian Construction Industry.}

This sub-section takes the survey results one step further by assessing the maturity level of project management practices for the contracting organizations working in the construction sector in Egypt. Such maturity level indicates the status of project management in the construction sector in the country and also shows what is achievable in the future. In Egypt, a few contracting organizations in the construction sector were found to be even aware of project management maturity models. An assessment of the project management maturity for the contracting organizations can provide useful information on the overall level of project management practices of these organizations and can be another essential input to decide on 
the path forward to establish the basis of development of maturity framework that meets their current status and their requirements more closely.

Although not all organizations implement project management maturity models, however it is possible to assess their maturity levels. One such framework was proposed by Kwak and Ibbs [27]. An assessment exercise for the maturity levels for organizations have been conducted in several countries by distribution of a questionnaire to such organizations. Theses assessment methodologies provide overview and helpful information on the state of project management practices within the country. Examples of these countries are South Africa [12], Switzerland [13], Mauritius [11] [9], Ethiopia [15], Portugal [20], Kazakhstan [2] etc. A similar survey was carried out in Egypt and included in the Expert Judgement survey to determine the maturity level of the Egyptian construction contractors.

Analysis of Survey Data

The ten knowledge areas as per the PMBOK standard, Fifth Edition [29] were considered in addition to the four knowledge areas related to the construction extension [30] forming a total no. of 14 knowledge areas as follows:

- Integration Management

- Scope Management

- Time Management

- Cost Management

- Quality Management

- Human Resources Management

- Communication Management

- Risk Management

- Procurement Management

- Stakeholder Management

- Safety Management

- Environmental Management

- Financial Management

- Claim Management

The above knowledge areas were mapped onto five maturity levels as per the information provided in P2M maturity model [251] and Soninke's and Launching [479] and as summarized in Table 1.The average maturity for an organization was calculated by averaging the values of the 14 knowledge areas. Then, the average for all organizations was calculated at the observed maturity. The results are shown in table 5.2.The computed average maturity level for Egyptian contracting organizations was found to be 1.44 and this possibly indicated an effort to achieve maturity level 2. However, concerned contracting organizations need to pursue their efforts further so as to achieve a world class standard, since these organizations were effectively operating at level 1. According to the description of maturity levels, the process, documentation management and metrics are considered to be at the basic level. It is imperative for Egyptian construction contractors to move to the next maturity level (i.e. level 2 ) in order to achieve further success in construction project management.

\section{Observed Maturity Level by Knowledge Area}

The average level of each knowledge area was calculated and the results are summarized in Table 1 and presented in Figure 2. As presented in the figure, most of the knowledge areas Egyptian Construction contractors scored and average maturity level above 1, except for risk management. It follows that Egyptian Construction contractors need to pay more attention to risk management, which may be a major cause of failure of construction projects.

Quality Management, cost Management and time management achieved the highest maturity levels compared to the other knowledge areas, Egyptian construction contractors, were, therefore, quite concerned about the basic tripe constrains. 
Table 1: Maturity Levels

\begin{tabular}{|c|c|c|c|c|c|}
\hline \multirow{3}{*}{$\begin{array}{l}\text { Maturity } \\
\text { Level }\end{array}$} & & \multirow[b]{2}{*}{ Level 5} \\
\hline & Level 1 & Level 2 & Level 3 & Level 4 & \\
\hline & Initial Process & $\begin{array}{l}\text { Structured Process \& } \\
\text { Standards }\end{array}$ & $\begin{array}{l}\text { Organizational Standards } \\
\text { and institutionalized } \\
\text { Process }\end{array}$ & Managed Process & Optimized Process \\
\hline Process & $\begin{array}{l}\text { No Established } \\
\text { Practices \& Standards }\end{array}$ & $\begin{array}{l}\text { Basic Processes exist, but are not } \\
\text { considered an organizational } \\
\text { standard. }\end{array}$ & $\begin{array}{l}\text { All project management } \\
\text { processes are in place and } \\
\text { established as organizational } \\
\text { standards. } \\
\text { Nearly all projects use these } \\
\text { processes. }\end{array}$ & $\begin{array}{l}\text { project management processes, } \\
\text { standards and supporting } \\
\text { systems are integrated } \\
\text { with other corporate processes } \\
\text { and systems. }\end{array}$ & $\begin{array}{l}\text { Processes are in place and } \\
\text { actively used to improve } \\
\text { project management activities }\end{array}$ \\
\hline Documentation & Loose \& Adhoc & $\begin{array}{l}\text { Documentation exists on the } \\
\text { basic processes. }\end{array}$ & $\begin{array}{l}\text { Documentation exists on all } \\
\text { the processes. }\end{array}$ & $\begin{array}{l}\text { Processes and standards are } \\
\text { documented to support using } \\
\text { metrics to } \\
\text { make project decisions. }\end{array}$ & $\begin{array}{l}\text { Lessons learned are regularly } \\
\text { examined and used to improve } \\
\text { project } \\
\text { management processes, } \\
\text { standards and documentation. }\end{array}$ \\
\hline Management & $\begin{array}{l}\text { Management } \\
\text { understands the } \\
\text { definition of a project, } \\
\text { and is aware of the } \\
\text { need for project } \\
\text { management. }\end{array}$ & $\begin{array}{l}\text { Management supports the } \\
\text { implementation of project } \\
\text { management, but } \\
\text { understanding and involvement } \\
\text { is not consistent / applied to all } \\
\text { projects. Large projects } \\
\text { are executed in a systematic } \\
\text { fashion, and management is } \\
\text { involved in such projects. }\end{array}$ & $\begin{array}{l}\text { Management is regularly } \\
\text { involved in input and } \\
\text { approval of key decisions }\end{array}$ & $\begin{array}{l}\text { Management understands its } \\
\text { role in the project management } \\
\text { process. } \\
\text { There are different management } \\
\text { styles and project management } \\
\text { requirements for different } \\
\text { projects. }\end{array}$ & $\begin{array}{l}\text { Management is focused not } \\
\text { only on effectively managing } \\
\text { projects but } \\
\text { also on continuous } \\
\text { improvement. }\end{array}$ \\
\hline Metris & $\begin{array}{l}\text { Collected informally on } \\
\text { an ad-hoc basis. }\end{array}$ & $\begin{array}{l}\text { Basic metrics to track cost, } \\
\text { schedule and technical } \\
\text { performance exist }\end{array}$ & $\begin{array}{l}\text { Metrics are formally } \\
\text { collected and each project is } \\
\text { evaluated and managed in } \\
\text { light of other projects }\end{array}$ & $\begin{array}{l}\text { Efficiency and effectiveness } \\
\text { metrics are used. All projects, } \\
\text { changes and issues } \\
\text { are evaluated based upon } \\
\text { metrics from cost estimates, } \\
\text { baseline estimates, and earned } \\
\text { value calculations. }\end{array}$ & $\begin{array}{l}\text { The metrics collected during } \\
\text { project execution are used to } \\
\text { understand the performance } \\
\text { of a project and to assist in the } \\
\text { making of organizational } \\
\text { management decisions } \\
\text { for the future. }\end{array}$ \\
\hline
\end{tabular}


Table 2: Maturity Levels by Knowledge Area

\begin{tabular}{|c|l|l|}
\hline Ser. & \multicolumn{1}{|c|}{ Project Management Knowledge Areas } & $\begin{array}{c}\text { Maturity } \\
\text { Level }\end{array}$ \\
\hline 1 & Project Integration Management & 1.03 \\
\hline 2 & Project Scope Management & 1.31 \\
\hline 3 & Project Time Management & 1.72 \\
\hline 4 & Project Cost Management & 1.72 \\
\hline 5 & Project Quality Management & 1.94 \\
\hline 6 & Project Human Resources Management & 1.50 \\
\hline 7 & Project Communications Management & 1.39 \\
\hline 8 & Project Risk Management & 0.94 \\
\hline 9 & Project Procurement Management & 1.60 \\
\hline 10 & Project Stakeholders Management & 1.18 \\
\hline 11 & Project Safety Management & 1.64 \\
\hline 12 & Project Environmental Management & 1.21 \\
\hline 13 & Project Financial Management & 1.61 \\
\hline 14 & Project Claim Management & 1.31 \\
\hline
\end{tabular}

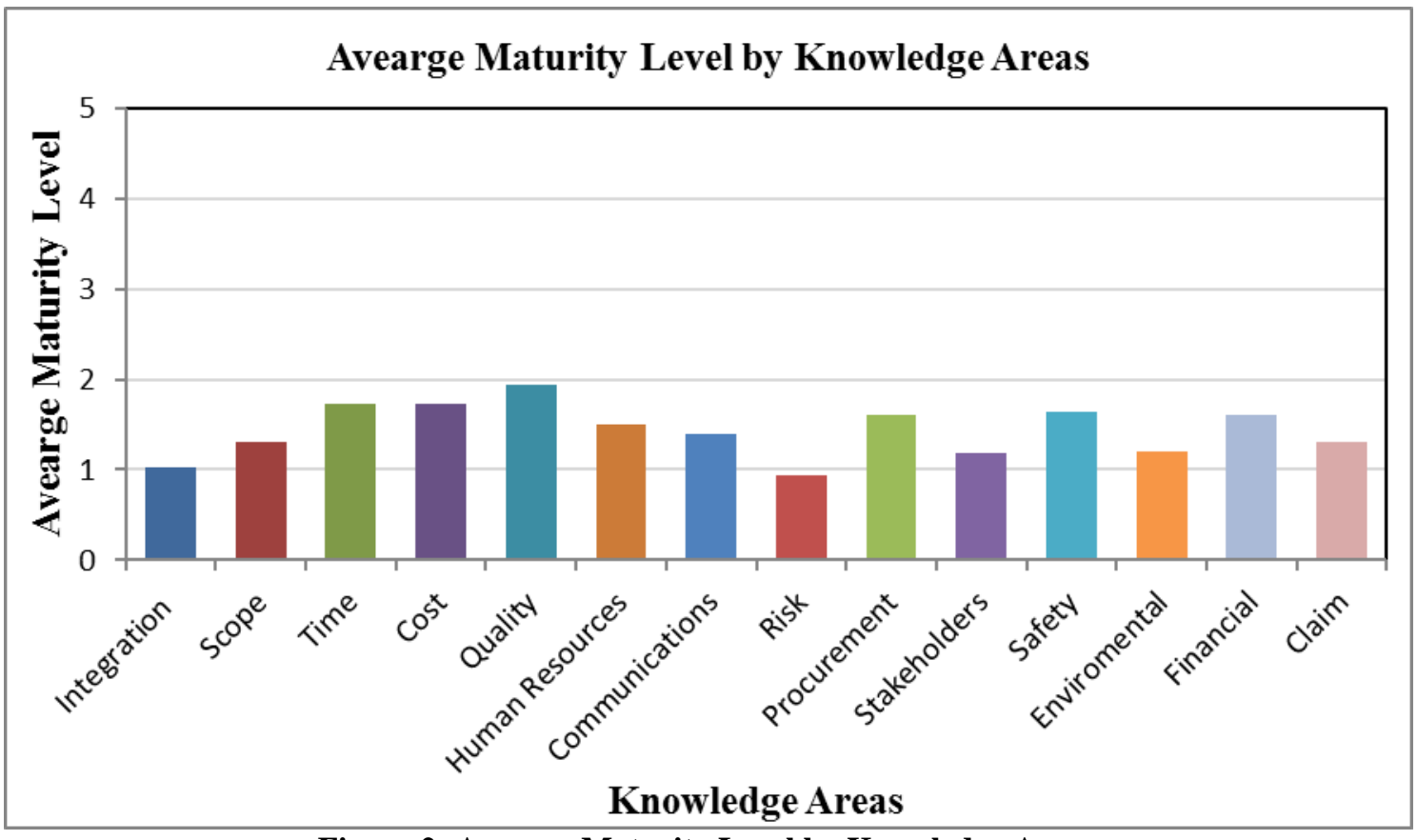

Figure 2: Average Maturity Level by Knowledge Areas 


\section{CONCLUSION, THE WAY FORWARD AND FURTHER STEPS}

In order to decide on the path forward regarding construction project management for Egyptian construction contracting organizations, the Expert judgement survey conducted targeted to have replies on two main questions in these organizations:

- The Awareness and Implementation of both Maturity Models and project management methodologies/ standards.

- Assessment of Construction Project Management Maturity Level.

The results of the survey were analyzed. It was found that the maturity level of Egyptian Contracting organizations working in the construction industry attained a level of almost 1 on a sale of 1 to5. Therefore, Egyptian Contracting organizations are still at the basic level and a lot of efforts are necessary to reach a higher level are clear.

Moreover, the following points, related to the Egyptian construction contracting organizations, could be noted as well:

- A lack of formal project management methodologies/ standards.

- A lack of awareness and implementation of project management maturity models.

- The need for best practices in the field of project management.

- The Project Management Institute's Standard for Project Management, "A Guide to the Project Management Body of Knowledge (PMBOK ${ }^{\circledR}$ Guide)" [29] is the most popular and known standard among construction contracting organizations in Egypt.

The results of this survey provides an insight into the awareness, implementation and current status of project management practices in the construction contracting organizations in Egypt. It could be noted that improvement is required so as to allow construction contracting organizations to deliver construction projects to contribute towards the vision set by the government. The construction contracting sector should evolve rapidly to extend the trade of construction contracting services with other countries and consequently meet the objective of developing it as one of the main pillars for the national economy.

Following the study of existing maturity models and the analysis of the current status of Egyptian construction contracting organizations through the expert judgement survey in this paper, we can affirm that Egyptian construction contractors would benefit from developing a maturity model adapted to the current status found in Egypt.

According to several previous studies and authors such as Kerzner [21], Sukhoo [11], Kwak and Ibbs [27], Schlitz [13], Soninke's and Launching [12], Archibald and Paradox [3] and several others have shown a direct relation between the project management maturity and project success. We conclude by noting the current survey the need for a maturity framework that can bridge the existing gap in construction project management between Egypt and developed countries to achieve the government vision of developing the contracting sector as one of the pillars for the national economy.

\section{REFERENCES}

1. Ofori, G. (2006). Construction in developing countries: A research agenda, Journal of Construction in Developing Countries.

2. Narbaev, T. (2015). An Assessment of Project Management Maturity in Kazakhstan.

3. Archibald, R. D., \& Prado, D. (2014). The Importance of Knowing Your Project, Program, and Portfolio Management Maturity: PPPMM. 
4. Idoko, L. A. (2008). Developing local capacity for project management - Key to social and business transformation in developing countries. PMI Global Congress 2008. Project Management Institute.

5. "Youm 7 Daily Newspaper", http://m2.youm7.com/story/2015/8/4, (2015), accessed August 4, 2015.

6. Adams, O. (1997). Contractor development in Nigeria: Perceptions of contractors and professionals. Journal of Construction Management and Economics, 15(1), 95108.

7. Long, N. D., Ogunlana, S., Quang, T., \& Lam, K. C. (2004). Large construction projects in developing countries: A case study from Vietnam. International Journal of Project Management, 553-561.

8. Dlungwana, W. S., \& Rwelamila, P. D. (2004). CONTRACTOR DEVELOPMENT MODELS THAT MEET THE CHALLENGES OF GLOBALISATION-A CASE FOR DEVELOPING MANAGEMENT CAPABILITY OF LOCAL CONTRACTORS. Globalization and Construction, 347.

9. Sukhoo, A., Barnard, A., Eloff, M. M., \& Poll, J. A. (2005). An assessment of software project management maturity in Mauritius. Issues in Informing Science and Information Technology, 2, 671-690.

10. Haar, R. (2008). Project, program and portfolio management in large Dutch organizations: determining the maturity of project, program, and portfolio processes and identifying bottlenecks in further professionalizing the project organization.

11. Sukhoo, A. (2009). An evolutionary software project management maturity model for developing countries (Doctoral dissertation, University Of South Africa).

12. Sonnekus, R., \& Labuschagne, L. (2004). Establishing the relationship between IT project management maturity and IT project success in a South African context. Proceedings of the 2004 PMSA Global Knowledge Conference, Johannesburg, South Africa, 183-192.

13. Schiltz, S. J. (2003). A practical method for assessing the financial benefit of project management (Doctoral dissertation, City University).

14. Paulk, M. C., Curtis, B., Chrissis, M. B., \& Weber, C. V. (1993). The capability maturity model for software, version1.1. Technical Report, Carnegie Mellon University, Software Engineering Institute, Pittsburg.

15. Yimam, A. H. (2011). Project management maturity in the construction industry of developing countries (the case of Ethiopian contractors) (Doctoral dissertation).

16. Axelos Limited. (2015b). Portfolio, program and project management maturity model (P3M3® version 3.0): Introduction and guide to P3M3®. Axelos Limited, London.

17. Axelos Limited. (2015a). Portfolio, program and project management maturity model (P3M3® version 3.0): Project model. Axelos Limited, London.

18. Archibald, R., Prado, D. (2014). Introduction to maturity in project management. PM World Journal, 3(1), 1-14.

19. Project Management Institute (PMI). (2013). Organizational Project Management Maturity Model (OPM3®) (3rd Ed.). Newtown Square, Pa: Project Management Institute.

20. Silva, D., Tereso, A., Fernandes, G., \& Pinto, J. Â. (2014). OPM3® Portugal project: Analysis of preliminary results. Procedia Technology, 16, 1027-1036.

21. Kerzner, H. R. (2002). Strategic planning for project management using a project management maturity model. John Wiley \& Son.

22. Crawford, J. K. (2015). Project management maturity model. CRC Press.

23. Chrissis, M. B., Konrad, M., \& Shrum, S. (2003). CMMI: Guidelines for process integration and product improvement. Addison Wesley.

24. Ahern, D. M., Clouse, A., \& Turner, R. (2008). CMMI distilled: A practical introduction to integrated process improvement (3rd Ed.). Upper Saddle River, NJ: Addison- Wesley Professional. 
25. IIL. (2015). Cerner PM maturity assessment. International Institute for Learning, Inc. Retrieved from http://www.iil.com/kpm3/how_kpm3_works.asp.

26. Ohara, S. (2005). P2M Guidebook. Retrieved from http://www.pmaj.or.jp/ENG/index.htm.

27. Kwan, Y.H. \& Bibs, C.W. (2002). Project management process maturity (PM) 2 Model [electronic version]. Journal of Management Engineering, 18(3), 150-155.

28. International Project Management Association. (2015). The IPMA Delta Model. Retrieved from http://ipma.ch/certification/certify-organisations/delta-referencemodel/

29. Project Management Institute (PMI). (2013). A guide to the project management body of knowledge (PMBOK guide) (5th Ed.). Newtown Square, Pa: Project Management Institute.

30. Project Management Institute. (2008). Construction extension to a guide to the project management body of knowledge, 3rd edition. Newtown Square, Pa: Project Management Institute. 